\title{
Konfliktni položaji med uradno osebo in stranko $v$ postopku izdaje gradbenega dovoljenja
}

UDK: 351.778.511(045)

\author{
Ksenija Oblak \\ Upravna enota Kranj \\ ksenija.oblak@gov.si
}

\section{IZVLEČEK}

\begin{abstract}
Postopek izdaje gradbenega dovoljenja je posebni upravni postopek, ki ga ureja Zakon o graditvi objektov (ZGO-1), subsidiarno pa Zakon o splošnem upravnem postopku (ZUP). Uradne osebe so pri vodenju gradbenega postopka soočene $z$ usklajevanjem in odločanjem med javnim in zasebnim interesom, poleg tega so v postopku poleg vložnika zahtevka udeleženi tudi stranski udeleženci, kar lahko pripelje do uveljavljanja nasprotujočih si zahtevkov. Ravno zato so uradne osebe pri vodenju in odločanju vse bolj priča neprimernemu vedenju in ravnanju strank, njihovim pritiskom, ustrahovanjem in grožnjam. Cilj prispevka je prikazati dejavnike, ki onemogočajo, da bi bili postopki hitrejši in učinkovitejši in osvetliti pomen odnosa med uradno osebo ter stranko. Članek poleg razlogov, ki povzročajo nezadovoljstvo strank, s pomočjo izvedene ankete prikazuje neraziskano in neevidentirano področje nedopustnih in nezakonitih posegov v delo uradnih oseb pri vodenju in odločanju v postopku izdaje gradbenega dovoljenja.
\end{abstract}

Ključne besede: postopek izdaje gradbenega dovoljenja, nezadovoljstvo strank, neprimerno vedenje strank, nedopustni in nezakoniti posegi v delo uradnih oseb.

JEL: $H 83$

\section{Odnos med uradno osebo in stranko $v$ postopku izdaje gradbenega dovoljenja}

Za uradnike, ki vodijo postopke izdaje gradbenih dovoljenj in $v$ njih odločajo, veljajo načela uslužbenskega sistema, kot so določena z Zakonom o javnih uslužbencih (ZJU). Tako morajo med drugim pri izvrševanju svojih nalog 
Ksenija Oblak

Konfliktni položaji med uradno osebo in stranko

v postopku izdaje gradbenega dovoljenja

ravnati zakonito, strokovno, častno, zaupno, zanje veljajo omejitve in dolžnosti v zvezi s sprejemanjem daril, svoje naloge morajo opravljati tudi politično nevtralno in nepristransko. $V$ ravnanje uradnih oseb torej ni vključeno le zakonito in strokovno izvrševanje nalog, temveč zanje veljajo tudi moralne in etične norme, glede na to, da $\vee$ postopku prihajajo $\vee$ stik s strankami. Ustrezne odnose med uradnimi osebami in strankami prav tako ureja Zakon o državni upravi (ZDU-1), ki varuje posameznika pred neustavnim, nezakonitim in neetičnim ravnanjem uprave. Zapovedi ravnanja, ki ustrezajo liku etičnega uradnika, določa tudi Kodeks ravnanja javnih uslužbencev, ki vsebuje zbirko moralnih pravil za to poklicno skupino. Po določbah tega kodeksa je uradna oseba med drugim zavezana, da pri opravljanju svojih nalog spoštuje človekovo dostojanstvo in je $v$ odnosih $z$ državljani spoštljiva.

Po drugi strani mora biti tudi odnos strank do uradnih oseb korekten in pošten. Uradne osebe, ki postopke izdaje gradbenih dovoljenj vodijo oziroma v njih odločajo, so vse bolj priča neprimernemu vedenju in ravnanju strank, konfliktnost med javno koristjo in interesom stranke pa nedvomno povzroča pritiske in nedopustno vmešavanje strank $v$ proces odločanja. Tudi sicer velja, da uradniki ne uživajo ravno visokega družbenega ugleda, nizka pravna kultura in potrošniška družba pa vse bolj povzročata, da se agresivnost strank - zlasti investitorjev - $v$ odnosu do uradne osebe stopnjuje.

\section{Razlogi, ki onemogočajo hitro in učinkovito vodenje postopka}

Tudi na področju izdajanja gradbenih dovoljenj se z antibirokratskimi programi ter s programi odpravljanja administrativnih ovir, prijazne in učinkovite državne uprave skuša doseči zadovoljstvo in usmerjenost k stranki. Vendar zadovoljstva uporabnika ne smemo postavljati pred interese drugih ali pred javni interes. Javna uprava namreč včasih svojo kakovost izkaže tudi tako, da uporabnika ne zadovolji, ko npr. zavrne njegovo zahtevo za gradbeno dovoljenje (Virant, 2003, str. 68).

Zadovoljstvo stranke so poudarjali tudi ob sprejemu novega ZGO-1, saj se je napovedovala poenostavitev postopka, novi zakon pa naj bi po besedah takratnega ministra predvsem bistveno skrajšal postopke. $\vee$ praksi obljub o poenostavitvi in skrajšanju postopka že zgolj zaradi dejstva, da se je število stranskih udeležencev 


\section{Konfliktni položaji med uradno osebo in stranko $v$ postopku izdaje gradbenega dovoljenja}

zaradi območja za določitev strank ${ }^{\mathbf{1}}$ povečalo in da izvedba skrajšanega ugotovitvenega postopka skorajda ni več možna, večinoma ni mogoče izpolniti. Dodatno postopke izdaje »klasičnih» gradbenih dovoljenj upravnim enotam podaljšuje tudi z ZGO-1B uvedena novost - izdaja gradbenih dovoljenj za nezahtevne objekte, saj je povečala obseg dela prvostopenjskih upravnih organov. Posledično se zaradi obljub o poenostavitvi in skrajšanju postopka, s katerimi se skuša velikokrat doseči zgolj večjo prijaznost do volilcev, izvajajo pritiski na uradne osebe, ki te postopke vodijo. Vsebinsko ustrezno bi bilo uporabnike tudi opozoriti na njihove obveznosti in tudi na druge pravice, ki brez ogrožanja javne koristi omogočajo hitrejše potekanje postopkov (Kovač, 2008, str. 8).

Vendar dejavniki, ki onemogočajo hitro vodenje postopka, še zdaleč niso samo na strani uradne osebe. Velika večina projektov, predloženih zahtevkom, je namreč pomanjkljivo izdelanih, zato jih je treba vračati v dopolnitev, saj ne vsebujejo niti najosnovnejših podatkov, ki so potrebni za presojo upravičenosti izdaje dovoljenja. Že samo morebitna manjkajoča soglasja lahko podaljšajo postopek za več mesecev.

Projekti se velikokrat izdelujejo izključno na podlagi zahtev investitorjev, ne pa na podlagi predpisov, zato je treba zahteve zavrniti, mnogokrat tudi zato, ker gradnja sploh ni mogoča. Tudi sama vsebina projekta se stalno spreminja, dodajajo se nove vsebine ter povečuje obseg izjav in raznih potrdil. Arhitekt Peter Gabrijelčič (v: M. M., 2009) ugotavlja, da se je na postopek priprave projektne dokumentacije $\vee$ nekaj letih "obesilo « kar nekaj novih strok, ki želijo primakniti lonček $k$ delitvi investicijskega denarja, in da je zato pridobitev gradbenega

1 Zakon o spremembah in dopolnitvah Zakona o graditvi objektov (ZGO-1B, Uradni list RS, št. 126/2007) je močno posegel na področje določanja strank $v$ postopku. ZGO-1B nadomešča določitev vplivnega območja objekta kot podlage za določanje stranskih udeležencev z območjem za določitev strank. V praksi kriteriji za določitev območja že sprožajo številne pomisleke, zlasti zato, ker je treba pri posameznih gradnjah vključiti v postopek veliko število stranskih udeležencev (npr. $v$ primeru spremembe namembnosti prostora $v$ večstanovanjskem objektu se določi izredno široko območje, ker je treba upoštevati stavbo kot celoto (tudi pri dozidavah). Pri gradnji objektov gospodarske javne infrastrukture se območje določi nekaj metrov od osi kanala, tako da je v postopek vključenih tudi do sto stranskih udeležencev, čeprav ima izgradnja takšnega omrežja vpliv na okolico le $v$ času gradnje)). Večje kot je območje za določitev strank, večje je tudi število stranskih udeležencev, ki so $v$ postopek vključeni zaradi služnostnega razmerja. Poleg tega je ZGO-1B položaj stranskega udeleženca podelil tudi občini, a le če na poziv upravnega organa priglasi udeležbo $v$ konkretnem postopku, zaradi česar se postopek podaljša za osem dni.

Tudi sama sem v okviru magistrske naloge, na vzorcu 30 konkretnih postopkov izdaje gradbenih dovoljenj, ki sem jih vodila v letih 2003-2008 ugotavljala, kolikšno bi bilo število stranskih udeležencev, če bi se določali po merilih, ki jih je uveljavil ZGO-1B. Rezultat analize je pokazal, da bi bilo v kar $60 \%$ izpostavljenih zadev število stranskih udeležencev večje, kot jih je dejansko sodelovalo $v$ postopkih, ki so bili vodeni po določbah ZGO-1, oziroma celo $v$ $90 \%$, če bi občine v vseh postopkih priglasile svojo udeležbo. 
Ksenija Oblak

Konfliktni položaji med uradno osebo in stranko

v postopku izdaje gradbenega dovoljenja

dovoljenja za enodružinsko hišo skorajda tak podvig, kot bi pridobivali dovoljenje za jedrski reaktor.

Omembe vreden razlog, ki otežuje odločanje v postopku, so tudi preohlapni in nedoločni prostorski akti. Če so ti namreč jasni, se preveritev skladnosti projekta s prostorskim aktom lažje opravi, zato se tudi postopki hitreje izvedejo. Počasen pristop občin $k$ ažuriranju obstoječih prostorskih aktov in sprejemanju novih se odraža tudi v nezadovoljstvu investitorjev, saj zastareli prostorski akt, ki se oklepa starih vzorcev, praviloma ne omogoča realizacije investitorjevih ciljev.

Za popolno obravnavo predmetnega področja morajo uradne osebe obvladati veliko število predpisov, saj ne zadošča zgolj poznavanje ZUP in ZGO1, ampak je vsaka gradnja vezana tudi na pogoje, ki jih določajo drugi predpisi. Zlasti se je razbohotila okoljevarstvena zakonodaja, saj je sestavljena iz več zakonov in preko 200 uredb, pravilnikov in odredb. Obširnost zakonodaje sama po sebi ne bi bila problematična, če se ne bi pogosto menjavala - tudi z nedomišljenimi in hitrimi spremembami in dopolnitvami. Tudi ZGO-1 je primer predpisa, ki zadeva veliko ljudi in pravnih oseb, pa se praktično dnevno spreminja, kar vnaša $v$ delovanje države vprašljivo pravno varnost (Kovač, 2004, str. 321, opomba 31). Tudi ZUP se $v$ kontekstu družbenih sprememb seveda stalno spreminja. Toda praksa zadnjih let kaže na pretirano dinamiko noveliranja, ki zlasti pri sistemskih zakonih $\vee$ končni posledici ustvarja nasprotje pravni državi, saj spremembam tako, da bi jih vsebinsko obvladale, ne sledijo niti uradne osebe, kaj šele stranke. V letih 2000-2008 se je ZUP spremenil in dopolnjeval kar s sedmimi posegi $v$ osnovno besedilo (novele A-F in ZUS-1), kar je tudi $v$ primerjavi s spreminjanjem jugoslovanskega ZUP - v letih 1956-1986 namreč štirikrat - očitno pretirano (Kovač, 2008, str. 2-3).

\section{Nezadovoljstvo strank in konfliktni položaji}

Nezadovoljstvo uporabnikov storitev javne uprave je delno vgrajeno $v$ poslovanje javne uprave, saj javnost njenega delovanja pogosto ne dojema kot zadovoljevanje svojih potreb, temveč kot (birokratsko) oviro na poti do zadovoljevanja potreb (npr. pri gradnji hiše) ali pa vsaj kot nujno zlo (po: Virant, 2003, str. 68). Določeno mero nezadovoljstva pri strankah še vedno povzroča ukoreninjena miselnost, da se « javni upravi bolj malo dela». 
Uravnoteženje različnih interesov, vpletenih $v$ gradbeni postopek, in veliki finančni vložki posameznih udeležencev postopka oziroma njihova tveganja tudi na obravnavanem področju povzročajo nezadovoljstvo strank. Področje nepremičnin je namreč ena izmed najbolj donosnih gospodarskih panog $\vee$ naši državi; vsak kvadratni meter stanovanjske površine pomeni pravo bogastvo. $V$ primeru, ko investitor želi postaviti npr. za tretjino večji objekt od dovoljenega, bi si pridobil nekaj sto tisoč evrov protipravne premoženjske koristi, zato so apetiti investitorjev včasih brezmejni. Vse, kar stoji med njimi in še bolj bajnimi dobički, po njihovem mnenju ni prostorski akt, temveč uradnik, ki skrbi za dosledno izvajanje tega predpisa (po: K. M., 2007).

Uradne osebe so zato pogosto izpostavljene neprimernemu vedenju in ravnanju strank, njihovim "navodilom", "spodbudam" ter različnim oblikam pritiskov in ustrahovanj, in sicer z namenom, da bi bilo njihovo delo usmerjeno $\checkmark$ odločitve, ki so za stranke najugodnejše ter pomenijo hitro in ugodno rešitev zadeve. Redki niso niti primeri, ko so uradne osebe izpostavljene celo različnim oblikam groženj - tako neposrednim kot posrednim. Direktne grožnje se izrekajo po telefonu ali na način, da je dokazovanje, da so sploh bile izrečene, težje. Še bolj problematične so grožnje, ki so izrečene po "posrednikih«. Za ustrahovanje uradnikov se uporabljajo tudi bolj prefinjene metode, kot so zasledovanja uradnikov $\vee$ zasebnem življenju, poškodovanje njihovega premoženja, «vljudnostni obiski« ipd. (po: OZP, 2008). Nezadovoljne stranke se vse pogosteje poslužujejo tudi kazenskih ovadb uradnih oseb, najpogosteje zaradi zlorabe uradnega položaja in uradnih pravic.

Po mnenju Vrtačnika (2007, str. 466) do tako številnih kazenskih ovadb za to kaznivo dejanje prihaja tudi zato, ker nezadovoljni občani pa tudi osebe, ki so nagnjene $k$ temu, da se pogosto obračajo na različne institucije, vlagajo kazenske ovadbe zoper policiste, tožilce, sodnike, državne uradnike in funkcionarje, ker so nezadovoljni z njihovimi odločitvami ali izidom postopkov, ki so se zanje končali neugodno. Nadalje navaja, da tožilci celo ugotavljajo, da so nekatere kazenske ovadbe posameznikov motivirane z maščevalnostjo do uradnih oseb, ko stranke ne uspejo s svojimi zahtevami - predvsem $v$ sodnih in upravnih postopkih na prvi stopnji. 
Ksenija Oblak

Konfliktni položaji med uradno osebo in stranko

v postopku izdaje gradbenega dovoljenja

\section{Raziskava o prisotnosti neprimernega vedenja strank in o njihovih nedopustnih posegih $v$ delo uradnih oseb}

\subsection{Zasnova in izvedba raziskave}

Z empirično raziskavo, ki je bila izvedena po metodi anketiranja ${ }^{2}$ zapos- $^{-}$ lenih $^{\mathbf{3}}$, sem želela ugotoviti, ali so uradne osebe $v$ praksi pogosto izpostavljene neprimernemu vedenju in ravnanju strank oziroma celo ali so podvržene različnim pritiskom, grožnjam, ustrahovanju in drugim oblikam nedovoljenih posegov $\vee$ njihovo vodenje postopka in odločanje. $\vee$ raziskavo so bile vključene tiste uradne osebe, ki so bile pripravljene sodelovati $v$ raziskavi in ki vodijo in odločajo $\vee$ postopkih izdaje gradbenih dovoljenj za zahtevne in manj zahtevne objekte na prvi stopnji.

Prejela sem 75 izpolnjenih anket, kar je relativno dober odziv. Glede na specifično populacijo in usmerjenost ankete na uradne osebe, ki dobro poznajo preučevano problematiko, saj se z njo vsakodnevno srečujejo, lahko rezultate raziskave štejem za dokaj zanesljive in verodostojne. Odgovori seveda odražajo tudi subjektivna stališča anketirancev.

\subsection{Predstavitev rezultatov raziskave}

$\mathrm{Na}$ anketni vprašalnik je odgovorilo nekaj več kot 81 \% žensk in skoraj 19 \% moških, kar odraža splošno strukturo vseh zaposlenih glede na spol v upravnih enotah. Glavnina vseh anketirancev je bila starejših od 35 let, le dobra četrtina sodelujočih je bila mlajših od njih. $V$ analizo je bilo zajetih približno enako število anketirancev upravne, pravne in gradbene oziroma arhitekturne smeri, vsakih približno četrtina, kar pomeni, da je bila strokovna usposobljenost anketirancev na visoki ravni.

2 Anketiranje je bilo izvedeno s pomočjo anketnih vprašalnikov. Anketiranci so bili opozorjeni, da želim z anketo izmeriti morebitno prisotnost neprimernega vedenja, pritiskov in groženj, povzročenih oziroma usmerjenih nanje le od strank, torej investitorja, stranskih udeležencev in tretjih oseb, ki želijo vstopiti v postopek izdaje gradbenega dovoljenja z uveljavljanjem pravnega interesa. Anketni vprašalnik je bil zasnovan kot vprašalnik z 19 vprašanji zaprtega tipa in enega vprašanja odprtega tipa, pri katerem je bila ponujena možnost, da anketiranci komentar vpišejo sami. $V$ tem prispevku so predstavljeni odgovori na večino vprašanj. Anketa je bila izvedena od 7. 9. 2009 do 5. 10. 2009.

3 Anketirance sem izbrala tako, da so bile $v$ raziskavo zajete uradne osebe s petnajstih teritorialno različnih upravnih enot, pomemben kriterij za izbor pa je bila tudi velikost upravne enote. Anketni vprašalniki so bili namreč poslani v manjše upravne enote in tudi $v t$. i. večje. Zaradi zagotovitve popolne anonimnosti anketirancev upravnih enot poimensko ne navajam. 
Anketiranci so bili najprej vprašani, ali so pri svojem delu pogosto izpostavljeni neprimernemu vedenju in ravnanju strank. $V$ anketi sem podala šest izbranih oblik neprimernega vedenja in ravnanja. Rezultati so pokazali - kar je zaskrbljujoče - da je bila skorajda polovica anketirancev (49,33\%) pogosto izpostavljena nevljudnemu ali nespoštljivemu govoru oziroma obnašanju strank. Podatki kažejo na visok delež tistih, ki so bili pogosto izpostavljeni tudi omalovažujočem ali žaljivem govoru in obnašanju (37,33 \%) ter smešenju, podcenjujočemu govoru in obnašanju (34,67\%). Na četrtino anketirancev $(25,33 \%)$ so stranke pogosto kričale ali jih zmerjale, kar slaba petina $(18,67 \%)$ jih je bila pogosto deležna kletvic ali prostaških izrazov. Upam si trditi, da je anketirani, ki je obkrožil, da je pogosto izpostavljen telesnemu napadu, nekoliko nedosledno odgovoril na vprašanje. Predvidevam, da je bila ta uradna oseba pri svojem delu že izpostavljena telesnemu napadu in da je to storila stranka, kar je zagotovo zelo zaskrbljujoče. Glede na to, da število odgovorov ni bilo omejeno, rezultati kažejo, da anketiranci pogosto doživljajo več oblik neprimernega vedenja in ravnanja strank.

Rezultati vprašanja, ali so anketirani že bili deležni očitkov, navedenih $v$ anketnem vprašalniku, pokažejo, da so stranke največkrat $(86,67 \%)$ očitale uradnim osebam odgovornost za ureditev, za katero te niso odgovorne. Temu pričakovano sledi očitek o birokratskem odnosu in togosti (77,33 \%). Dokaj pogosto ( $v$ nekaj več kot $40 \%$ ) so uradnim osebam stranke očitale pristranskost ali nezakonitost, sledijo očitki, da uradne osebe načrtno nagajajo $(30,67 \%)$, da so nestrokovne $(22,67 \%)$ in koruptivne $(17,33 \%)$. Izsledki analize kažejo, da stranke najredkeje očitajo arogantnost $(14,67 \%)$, pomanjkanje delovnih navad in lenobo $(10,67 \%)$, maščevalnost $(9,33 \%)$ ter politično pristranskost (4,00 \%). Zadnji očitek so zaznali le trije anketiranci.

$Z$ anketo sem želela tudi izmeriti prisotnost nedovoljenih usmeritev in navodil strank uradnim osebam, kako naj se vodijo postopki izdaje gradbenih dovoljenj, kateri dokazi naj se izvajajo in kako naj se $v$ upravni zadevi odloči. Velika večina anketirancev, kar $84 \%$, je navedla, da je bila priča tovrstnim usmeritvam ali pa da se stranke niso strinjale z njihovimi strokovnimi odločitvami. Če sem iz odgovorov na gornje vprašanje ugotovila, da je bila velika večina anketirancev že deležna nedopustnih posegov $\vee$ svoje delo, sem iz odgovorov na naslednje zastavljeno anketno vprašanje ugotovila, da je skupni delež odgovorov, ki potrjujejo, da so bile anketirane osebe že "napeljevane» h kršitvi zakonov in drugih predpisov, skoraj 58,67-odstoten. 


\section{Ksenija Oblak}

\section{Konfliktni položaji med uradno osebo in stranko}

v postopku izdaje gradbenega dovoljenja

Za merjenje pojavnosti korupcije s stranko kot pobudnikom je bilo zastavljeno vprašanje: Ali vam je bila od strank že posredno ali neposredno obljubljena, ponujena ali dana podkupnina, da bi opravili dejanje, ki ga ne bi smeli opraviti, da ne bi opravili dejanja, ki bi ga morali ali smeli opraviti, oziroma da bi kako drugače zlorabili svoj položaj? Natanko $80 \%$ anketirancev je na zastavljeno vprašanje odgovorilo negativno, preostala petina $(20 \%)$ pa je potrdila, da so stranke z zaznanimi koruptivnimi dejanji želele vplivati na postopek in vsebino odločitve.

Iz spodnjega grafikona je razvidno, da se pritiski in grožnje strank povečujejo - temu pritrjuje $60 \%$ anketirancev. $20 \%$ anketirancev je očitno v dvomu, povsem enak delež je tudi tistih, ki menijo, da to ne drži, torej da se pritiski in grožnje ne povečujejo. Vprašanje je bilo časovno navezano na obdobje od uveljavitve ZGO-1, poleg tega pa ravno $v$ obdobju od leta 2003 do 2008 beležimo največjo povprečno letno rast cen nepremičnin $\vee$ RS, kar se je odražalo tudi v povečanem številu izdanih gradbenih dovoljenj.

\section{Grafikon 1: Mnenja anketirancev o tem, ali se pritiski in grožnje strank povečujejo}

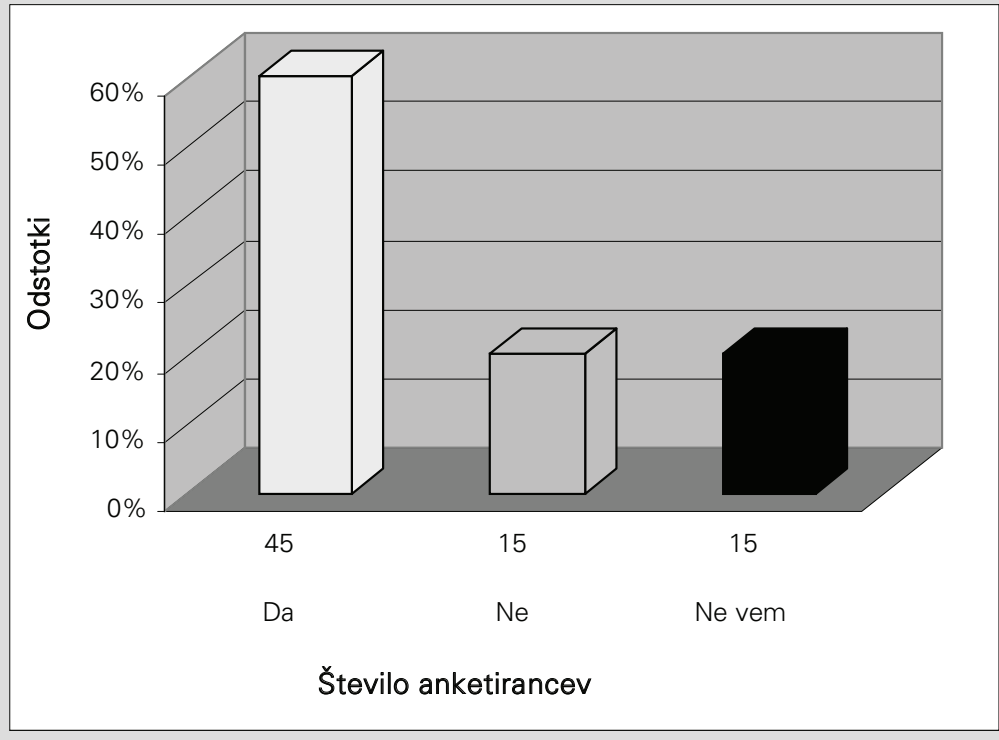


Glede na pogostost izpostavljenosti pritiskom in grožnjam so rezultati pokazali, da je bila nekaj več kot polovica anketirancev (53,33 \%) redko izpostavljena pritiskom in grožnjam, medtem ko nihče ni označil, da jim je bil izpostavljen dnevno. Slaba četrtina $(24,00 \%)$ je ocenila, da so bili pogosto izpostavljeni, kar je zelo zaskrbljujoče in problematično, saj vpliva na kakovost dela, še zlasti če zanemarimo notranje pritiske nadrejenih. 22,67 \% anketirancev pritiskov in groženj nikoli ni zaznalo. Na vprašanje, kdo je tisti, ki najpogosteje izvaja pritiske in grožnje, lahko ugotovimo, da z absolutno večino vodi investitor, kot je navedlo 65,38\% anketirancev, nato pa se podatki o povzročiteljih precej uravnovesijo. Na drugem mestu je stranski udeleženec $(13,46 \%)$, nizko sta ocenjena tretja oseba in predstavnik občine $(9,62 \%$ oziroma 7,69 \%). 3,85 \% anketirancev je navedlo, da so bili pritiskov in groženj deležni od izdelovalca projekta, ki sicer ni stranka v obravnavanem postopku, a je bil vseeno naveden v vprašalniku kot možni povzročitelj.

Kot ključne vzroke, ki vplivajo in pripomorejo k temu, da so bile izpostavljene različnim oblikam pritiskov, ustrahovanj in grožnjam, so uradne osebe najpogosteje prepoznale nizek ugled institucij oziroma javnih uslužbencev (80,65\%). Sledijo odgovori, da so to osebna nestrpnost posameznikov oziroma njihova nizka osebna kultura $(77,42 \%)$, dobičkonosnost na področju graditve objektov $(77,42 \%)$ in normativna neurejenost zaščite javnih uslužbencev oziroma njena nedorečenost $(69,35 \%)$. Nekoliko manj anketiranih je vzrok pripisalo dejstvu, da se storilcev, ki grozijo uradnim osebam, ne preganja $(59,68 \%)$, za njim pa so uvrstili visoko stopnjo tolerance $v$ družbi $(51,61 \%)$, nizko pravno kulturo $(48,39 \%)$ in sodobno potrošniško družbo $(48,55 \%)$.

Iz Grafikona 2 je razvidno, da so stranke s pritiski in grožnjami najpogosteje želele doseči ugodnejšo obravnavo vloge $v$ materialnem smislu (npr. neusklajenost projekta z določbami prostorskega akta), kot je to navedlo $46 \%$ anketirancev, malo manj (29\%) jih je odgovorilo, da je bil razlog $v$ zahtevi stranke po prednostni obravnavi vloge, kar je razumljivo, saj se strankam vedno zdi prednostna večinoma le njihova vloga. $14 \%$ anketirancev je kot razlog prepoznalo zahtevo po hitrejši obravnavi vloge (npr. neupoštevanje zakonskih rokov), saj je hitrost reševanja za nekatere stranke ključna, le dobra desetina $(11 \%)$ pa je navedla, da je bil razlog $\vee$ ugodnejši obravnavi zahteve $\vee$ postopkovnem smislu (npr. nevabljenje stranskih udeležencev $\vee$ postopek). 
Ksenija Oblak

Konfliktni položaji med uradno osebo in stranko

v postopku izdaje gradbenega dovoljenja

\section{Grafikon 2: Razlogi, zaradi katerih so stranke izvajale pritiske} in grožnje

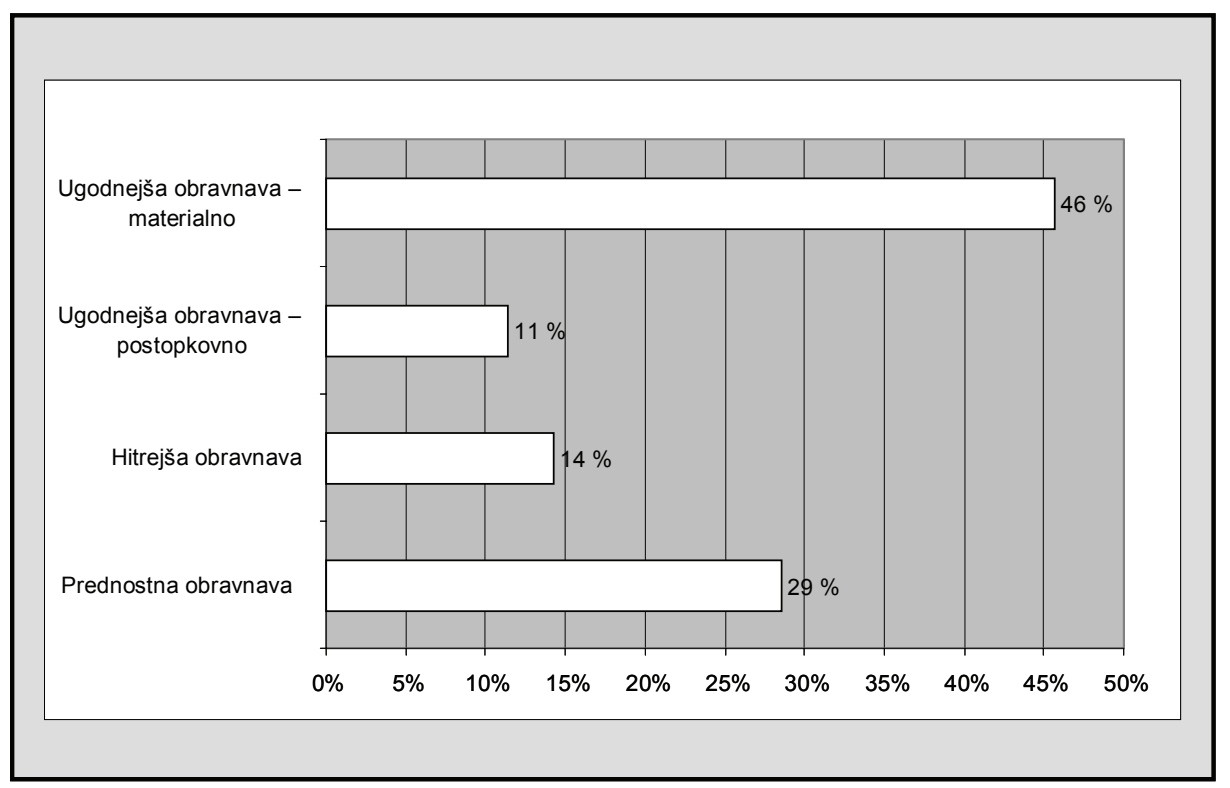

Glede na to, da verodostojne statistike o omenjenih ogrožanjih uradnih oseb ni, saj se različno evidentirajo, še večji problem pa je t. i. sivo polje, to je število neprijavljenih, a zaznanih dejanj (po: OZP, 2008), sem v anketo skušala zajeti podatke, ali so anketiranci nadrejenega seznanili, da so bili pri svojem delu deležni pritiskov in groženj, ter ali so grožnjo prijavili organom pregona. Analiza je pokazala, da je velika večina anketirancev, kar 92 \%, svojega nadrejenega obvestila o pritiskih in grožnjah, ki so jih bili deležni od strank. Povsem nasprotna pa je slika pri vprašanju: Ali ste grožnjo, ki vam jo je izrekla stranka, prijavili organom odkrivanja oziroma pregona? To je namreč storilo le 3,33 \% anketirancev, preostalih 96,67 \% pa ne. Zakaj tega niso storili, sem skušala ugotoviti iz podvprašanja - z njim sem tiste anketirance, ki so odgovorili negativno, pozvala, naj se izmed podanih razlogov odločijo za tiste, ki so $v$ njihovem primeru pretehtali, pri čemer je bilo mogoče navesti več odgovorov. 39,76 \% anketirancev je kot razlog navedlo relativno neprijetne postopke in težko dokazovanje, sledi odgovor, da obstaja majhna verjetnost, da bo storilec kaznovan $(31,33 \%)$, nato pa odgovor, da naj bi uradnik imel višjo stopnjo tolerance pri prejemanju izrečenih groženj (26,30\%). Strah pred storilcem očitno ni bil pogost razlog, saj se je zanj odločilo le 3,61 \% anketirancev.

$\mathrm{K}$ dodatnim mnenjem in komentarjem so bili anketiranci pozvani z vprašanjem, ali želijo glede obravnavane teme kaj dodati, s čimer naj bi dosegli 
subjektivnejši in izvirnejši odziv anketirancev. Anketiranci so navajali, da investitorji grozijo uradnim osebam z odškodninskimi tožbami ali s tem, da bo uradnik izgubil službo ter da nezadovoljstvo razglašajo povsod in tudi predpostavljenim, urgence za pospešitev postopka pa prihajajo z vseh mogočih strani, in to tudi takrat, ko je vloga komaj prispela na upravno enoto. Nadalje je bilo iz opisnih odgovorov zaslediti, da se večina pritiskov nanaša na predolge postopke, saj naj delodajalec ne bi zagotovil normalne količine dela, ki bi ga bilo mogoče opraviti $\vee$ rokih, zaradi česar so uradne osebe neprestano preobremenjene. Spet drugi so prepričani, da se pritiski in grožnje sicer zgodijo, vendar so bolj posledica nesocialnosti posameznika. Nekateri so $v$ odgovorih napisali, da imajo stranke vedno prav, da je treba biti do njih prijazen, četudi so žaljive, ter da takšne servilnosti in hlapčevstva delavcev upravnih organov proti strankam še ni bilo nikoli in sta nepotrebna, saj ni nujno, da se prijaznost do strank izkazuje s servilnostjo.

Zanimiva je ugotovitev, da so uradne osebe, čeprav so bile opozorjene, da je osnovni namen raziskave ugotavljati odnos med njo in stranko, $v$ odgovorih izpostavljale pritiske od nadrejenih. Tako so navedle, da se zadeva dostikrat hitreje obravnava in odobri, ker to zahteva vodja, da delodajalec izvaja pritiske in da vodstvo vselej verjame strankam in nikoli delavcem, zaradi česar so upravni delavci izgubili svoj ugled. To naj bi bilo po mnenju anketiranca povezano $z$ nastankom upravnih enot, ko vodstva delno iz strahu in delno iz preračunljivosti svojim ministrom ne pove, kaj se $v$ resnici dogaja.

\section{Sklepna misel}

Izvedena anketa je pokazala, da pritiski, grožnje in druga nedovoljena dejanja strank obstajajo, kar uradne osebe, ki postopke izdaje gradbenih dovoljenj vodijo oziroma $\vee$ njih odločajo, uvršča med javne uslužbence, kot so policisti, sodniki, cariniki in pazniki, ki so najpogosteje izpostavljeni tovrstnim oblikam nedovoljenih pritiskov in groženj. Pri tem je treba opozoriti, da anketiranci pritiskov in groženj, ki jih nanje izvajajo stranke, praviloma formalno ne prijavljajo, saj se bodisi ne želijo izpostavljati zaradi neprijetnih postopkov, bodisi je raven tolerance in občutljivosti do takšnih kršitev visoka. Da je to tako, je kriva tudi normativna neurejenost zaščite javnih uslužbencev. Tudi ta usmerja storilce $k$ takšnemu delovanju, saj štejejo, da so nedovoljena dejanja povsem družbeno sprejemljiva. Kaže pa, da grožnje uradnim osebam povzročijo hujše posledice kot korupcija, saj so nemalokrat javne, imajo svojo odmevnost in ustvarjajo 


\section{Ksenija Oblak}

\section{Konfliktni položaji med uradno osebo in stranko}

$v$ postopku izdaje gradbenega dovoljenja

splošno negativno klimo $\vee$ delovnih okoljih, $\vee$ katerih lahko ustvarjajo prave psihoze (po: OZP, 2008).

$\checkmark$ prihodnosti bi bilo treba zato več pozornosti posvetiti preprečevanju takšnih dejanj in ravnanj. Uradnik namreč ne more voditi postopka in $v$ njem odločati, če prihaja do nedovoljenih in nezakonitih posegov $v$ njegovo delo, poleg tega pa takšna dejanja vplivajo tudi na njegovo samozavest in motiviranost.

Ksenija Oblak je diplomirala na Visoki upravni šoli v Ljubljani v letu 1999. V študijskem letu 2004/2005 se je vpisala na specialistični študijski program Javna uprava, ki ga je v letu 2007 zaključila z delom na temo gradbenih dovoljenj. Sedaj zaključuje študij na podiplomskem magistrskem študijskem programu Uprava. Od leta 2001 je zaposlena na Upravni enoti Kranj, na kateri vodi postopke izdaje gradbenih dovoljenj. 


\section{Ksenija Oblak \\ Konfliktni položaji med uradno osebo in stranko v postopku izdaje gradbenega dovoljenja}

\section{Literatura in viri}

- $\quad$ K., M. (2007). Kdo bi rad ubil državne uradnike? Delo, 20. 1. 2007.

- Kovač, P. (2004). Vpliv mednarodnih načel, standardov in praks na (slovenski) upravni postopek. Javna uprava (2), 307-335.

- $\quad$ M., M. (2009). Dialog o prostoru postaja bojno polje. Dnevnik, 6. 6. 2009.

- Virant, G. (2003). Usmerjenost k uporabniku kot načelo delovanja javne uprave. Uprava (2), 67-82.

- Vrtačnik, M. (2007). Pregon kaznivih dejanj v javnem sektorju. Javna uprava (2), 459-472.

- Kovač, P. (2008). Upravni postopek med prijazno upravo in javnim interesom. XV. dnevi slovenske uprave. Portorož (1-11, elektronski vir). Ljubljana: Fakulteta za upravo.

- OZP. Ogrožanje varnosti uradnih oseb - novo kaznivo dejanje, predlog KZ-1. Najdeno 14. 5. 2009 na spletnem naslovu:

http://www.google.co.uk/search?hl=en\&num=50\&q=Ogro\% C5\%BEanje+varnosti+urad nih+oseb++novo+kaznivo+dejanje+po+KZ1\&meta=Ir\%3Dlang_hr\%7Clang_en\%7Clang _fr\%7Clang_de\%7Clang_sr\%7Clang_sl\%7Clang_es.

- Zakon o državni upravi (ZDU-1). Uradni list RS, št. 52/2002, 56/2003, 83/2003-UPB1, 45/2004-ZdZPKG, 61/2004, 97/2004-UPB2, 123/2004, 24/2005-UPB3, 93/2005, 113/2005-UPB4, 126/2007-ZUP-E, 48/2009.

- Zakon o graditvi objektov (ZGO-1). Uradni list RS, št. 110/2002, 97/2003 Odl. US: U-I152/00-23, 41/2004-ZVO-1, 45/2004, 47/2004, 62/2004 Odl. US: U-I-1/03-15, 102/2004UPB1 (14/2005 - popravek), 92/2005-ZJC-B, 93/2005-ZVMS, 111/2005 Odl. US: U-I150-04-19, 120/2006 Odl. US: U-I-286/04-46, 126/2007, 57/2009 Skl. US: U-I-165/09-8, $108 / 2009$.

- Zakon o javnih uslužbencih (ZJU). Uradni list RS, št. 56/2002, 110/2002-ZDT-B, 2/2004ZDSS-1 (10/2004 - popravek), 23/2005, 35/2005-UPB1, 62/2005 Odl. US: U-I-294/0415, 113/2005, 21/2006 Odl. US: U-I-343/04-11, 23/2006 SkI. US: U-I-341/05-10, 32/2006UPB2, 62/2006 Skl. US: U-I-227/06-17, 131/2006 Odl. US: U-I-227/06-27, 11/2007 Skl. US: U-I-214/05-14, 33/2007, 63/2007-UPB3, 65/2008, 69/2008-ZTFI-A, 69/2008-ZZavar-E, 74/2009 Odl. US: U-I-136/07-13.

- Zakon o splošnem upravnem postopku (ZUP). Uradni list RS, št. 80/1999, 70/2000, 52/2002, 73/2004, 22/2005-UPB1, 119/2005, 24/2006-UPB2, 105/2006-ZUS-1, 126/2007, 65/2008, 47/2009 Odl. US: U-I-54/06-32 (48/2009 - popravek).

- Kodeks ravnanja javnih uslužbencev. Uradni list RS, št. 8/2001. 
Ksenija Oblak

Konfliktni položaji med uradno osebo in stranko

v postopku izdaje gradbenega dovoljenja

\section{SUMMARY}

\section{CONFLICTS BETWEEN OFFICIALS AND CLIENTS APPLYING FOR BUILDING PERMIT}

The procedure of issuing a building permit is a special administrative procedure, regulated by the Construction Act which sets out the laws regarding the construction of buildings. Officials in charge of the procedure are nowadays facing serious misconduct from their clients, which is leading to pressures and inadmissible interference of clients in the procedure and decision making process. Often officials are accused of irregularities which they are not responsible for. Clients themselves of course strive for a quick positive resolution of the matter. There are many factors which prolong the whole procedure: insufficient and superficially realised projects, undefined spatial planning documents, constant change of numerous regulations. In addition to those factors there was an amending act put forward in the year $\mathbf{2 0 0 8}$ that enabled more people to interfere in the procedure.

The empirical study the author conducted in the autumn of 2009 helped with her research on the exposure of officials to inappropriate behaviour of clients, to verbal abuse and other forms of threats. Seventy five people from different municipalities in Slovenia took part in the survey, eighty one percent of them were female, nineteen percent male, with three quarters of the respondents younger than thirty five years.

The survey shows that the respondents often encountered different forms of misconduct and mistreatment from their clients. Almost half of them were exposed to verbal abuse. Most of them (37 percent) were often verbally abused and ridiculed ( 35 percent). A quarter of the respondents reported being yelled at and insulted, a fifth of them often encountered foul language used by their clients. Furthermore, the officials were accused of responsibility of the decree which they were not responsible for. As expected there was reproach about typical bureaucratic attitude (77 percent), biased and illegal approach (more than 40 percent) followed by accusation that officials did decide negatively on purpose (31 percent), that they were unprofessional (23 percent) and corrupt (17 percent). They were also accused of arrogance, lack of working habits, revenge and political bias.

A fifth of the respondents confirmed that the clients tried corruption in order to influence the procedure and the final decision. They (60 percent) 
also confirmed that the pressures and threats of the clients had increased since 2003, twenty percent of them doubted about that, and twenty percent of them did not agree with the fact that threats and pressures were increasing.

The survey shows that half of the respondents were rarely exposed to pressures and threats, and not a single person was exposed to them daily. A quarter of them thought that threats and pressure were quite common, a fifth of them never noticed any. Pressure mainly came from the investor as stated by 65 percent of the people surveyed, followed by a second party - (e.g. a neighbour) (13 percent), a third party (10 percent) and a municipality member (8 percent), four percent of them stated that they were threatened by project managers who were not clients in the ongoing procedure.

The main reason for being mistreated and threatened by the clients is most often low reputation of institutions and civil servants (81 percent). Another reason is personal intolerance of individuals (77 percent), followed by lucrative business of building (77 percent) and unregulated protection of civil servants (69 percent). There were some more possible reasons mentioned: people who threatened officials were not prosecuted; the society was too tolerant, it was a consumer society. As stated by 46 percent of the respondents, most clients wanted financially favourable solution.

The analysis shows that the majority of the respondents (92 percent) told their superiors about the pressures and threats, while only one third of them reported them to the law enforcement institutions.

Many respondents stated that the investors threatened them with compensation claim and even loss of job. Most of the pressures were related to long procedures and too short deadlines. Some of them think that threats are mainly conditioned by social immaturity of client, most of them think that clients are always right so they ought to be kind towards them even though they are offensive. The respondents also experienced some pressure from their superiors, demanding preferential treatment.

The survey proves that threats, pressures and other inappropriate acts exist and thus classify officials in the group of exposed civil servants like policemen, judges, customs officers, prison wardens. Illegally interfering with officials work hinders the procedure and also leads to a negative working environment. This is why in the future more attention should be paid to prevent such behaviour. 